\title{
The symptomatic bilaterally occlusive surfer's air (exostosis of the external auditory canal)
}

\author{
Bilateral semptomatik oklüzif sörfçü kulağı (eksternal kulak kanalı ekzositozu)
}

\author{
(D) Emrah Doğan, (1) Mustafa Kule, (1) Bunyamin Güney, (1) İlknur Altun, (1) Turhan Togan \\ Muğla Sttkı Koçman University Training and Research Hospital, Department of Radiology, Muğla, Turkey
}

Cite this article as / Bu makaleye atıf için: Doğan E, Kule M, Güney B, Altun İ, Togan T. The symptomatic bilaterally occlusive surfer’s air (exostosis of the external auditory canal). J Health Sci Med 2020; 3(3): 355-357.

\begin{abstract}
Surfer's ear is a disease characterized by a benign exostosis of the external ear canal. It is recognized by an otoscopic evaluation and manifests itself with one or several outgrowth lesions in the external ear canal. Although the characteristics of the disease are not known exactly, it is assumed that it may be due to the long-term exposure to cold water. Our case is about a 39 years old man admitted to the hospital with a difficulty in unilateral hearing. The complaints persisted for two months. Temporal computed tomography revealed narrowing of $40 \%$ on the left and $70 \%$ on the right. Other radiological findings were a loss of mastoid cells and sclerosis. The patient had also hypoplasia in the ethmoid sinuses. The patient doesn't have frequent contact with water but he was living in a windy city that is famous for paragliding.
\end{abstract}

Keywords: Surfer's air, bilaterally maxillary hypoplasia, paranasal sinuses computed tomography

\section{ÖZ}

Sörfçü kulağı eksternal kulak yolunun benign ekzostozu ile karakterize bir hastalıktır. Otoskopik değerlendirme ile tanınır ve dış kulak kanalında bir veya daha fazla ekzostotik lezyon ile kendini gösterir. Hastalığın özellikleri tam olarak bilinmemekle birlikte, uzun süreli soğuk suya maruziyet ana predispozan faktör olarak varsayılmaktadır. Olgumuz, tek taraflı işitme güçlüğü ile hastaneye başvuran 39 yaşında erkek hastaydı. Şikayetler iki aydır devam etmekteydi. Bilgisayarlı tomografide dış kulak yolunun solda \% 40 , sağda \%70 daraldığı saptandı. Mastoid hücre kaybı ve skleroz eşlik etmekteydi. Hastada ayrıca etmoid sinüslerde hipoplazi mevcuttu. Hastanın suyla sık teması yoktu. Ancak yamaç paraşütü ile ünlü rüzgarlı bir şehirde yaşıordu.

Anahtar Kelimeler: Sörf̧̧ü kulağı, maksiller hipoplazi, paranazal sinus bilgisayarlı tomografi

\section{CASE REPORT}

A 39 years old male patient was admitted in our hospital with unilateral decrease in hearing. His complaints have lasted from 2 months. In the anamnesis, the patient didn't report any symptoms concerning its ear in the past. $\mathrm{He}$ had seasonal allergic rhinitis and received cortisone treatment several times.

The patient lived in Fethiye, a coastal town. He did not do any maritime work. However, the patient reported spending time at the seaside at night and not swimming a lot during the summer season.

On examination, the external auditory canal appeared narrow. The epithelial residue from the external ear canal was aspirated however the eardrum could not be fully evaluated because of oedema. A retraction pouch or cholesteatoma was noted as a preliminary diagnosis.

In flexible laryngoscopy, adenoid vegetation and tonsillar hypertrophic crypts were found. The audiometry test revealed a $35 \mathrm{db}$ transmission loss in the right ear.

On temporal CT, exostosis was observed narrowing the external ear canal at almost $70 \%$ of its diameter, proximal to the right tympanic membrane. Narrow area of the external ear canal measured $1.5 \mathrm{~mm}$ (Figure 1a). More moderate exostosis narrowed the canal by $40 \%$ in the same anatomical region on the left (Figure 1b). Both external canal segments had an usual anatomy in other 
segments. There were densities filling epitympanum, aditus et antrum and mastoid antrum in both ears, more marked in the right. The appearance was compatible with otitis media (Figure 1c,1d). There was partial sclerosis in mastoid cells (Figure 2a). Minimal aeration was observed in several mastoid cells around the bilateral mastoid antrum. Shape and densities of the middle ear ossicles were normal.

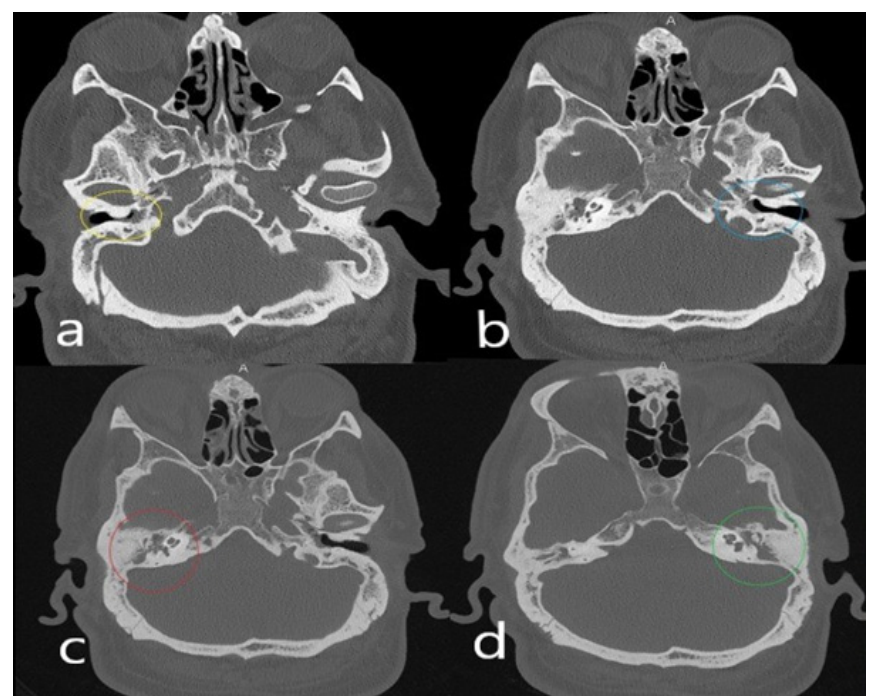

Figure 1. Exostosis that reduces the right external ear canal by $70 \%$ (a) Exostosis that reduces the left external ear canal by $40 \%$ (b) Soft tissue densities filling the attic cavity in favour of otitis media on the right (c) Soft tissue densities filling the attic cavity in favour of otitis media on the left (d)

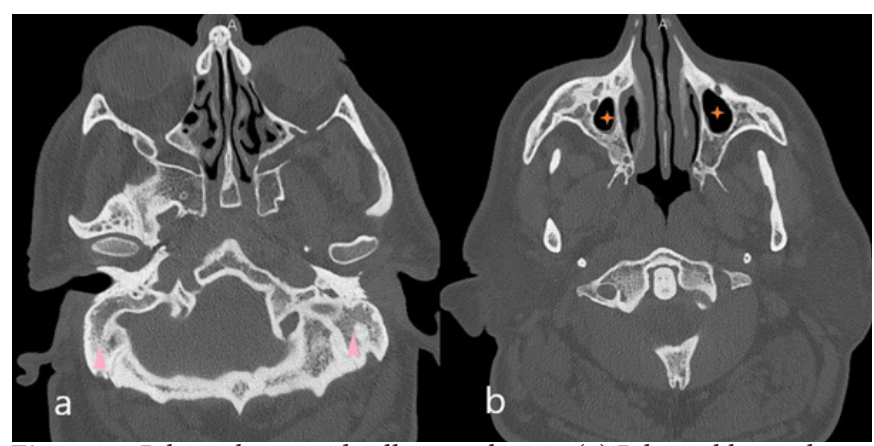

Figure 2. Bilateral mastoid cells are sclerotic (a) Bilateral hypoplastic maxillary sinuses (b)

Ethmoid and sphenoid sinuses had densities that were compatible with sinusitis. Several millimetric retention cysts were detected in ethmoid sinuses and in the maxillary base. Bilateral maxillary sinuses were moderately hypoplastic (Figure 2b). There was also a thickening of the nasopharyngeal lymphoid tissue at the right side.

Based on these findings, the patient was diagnosed with exostosis of the external auditory canal (surfer's ear).

\section{DISCUSSION}

Aural exostosis are typically hard, dense, multinodular bone masses that arise from the tympanic ring of the bone portion of the external auditory canal (1). This growth develops after prolonged irritation of the canal (2). It is more common in coastal areas $(1,2)$. It is also known as surfer's ear because it is common in surfers $(3,4)$. Although the cause of exostosis has not been established precisely, it has been clinically accepted that cold water exposure is the starting factor for temporal bone growth (5). We present a patient with bilateral exostosis of the external auditory canal and chronic changes due to chronic otitis and mastoiditis.

Exostosis of the external ear canal is a human-specific disease. Long-term contact of the external auditory canal with cold sea water is the most common cause (aquatic theory). The disease is mainly confined to coastal areas. The history of the current pathology is due to mechanical, chemical and environmental factors during 3 different periods of its evolution adding an interesting aspect to the disease (2). Exostosis represent the most common benign tumours of the external auditory canal (6). Also known as "surfers' ear (SE)", because of its high prevalence among surfers, it seems to be related to prolonged and repeated exposure to cold water (especially below $19^{\circ} \mathrm{C}$ ) (7). SE is a predominantly male disease (2). Professional surfers are more likely to have exostosis than amateur surfers. These exostoses are usually asymptomatic (3).

The development of these "irritation nodules" is painless until the tenth year of irritation when symptoms of obstruction occur (2).

They may cause in the affected ear, tinnitus, pain, itching, congestion, fullness, hearing loss, and recurrent otitis externa (3).

Hearing loss associated with exostosis is usually a conductive type secondary to obstruction of the canal by the cerumen or acute external otitis in the affected ear (2).

It is important to differentiate a simple exostosis from 3 other types of tumour which are Squamous cell carcinoma (SCC), external ear canal nevus (EECN) and osteosis.

SCC is the most common external canal cancer. The tumour is unilateral, haemorrhagic and progressive. These cancers typically have symptoms such as ear pain and hearing loss.

EECN presents in the form of a single black lesion, unilateral and sessile. The average size is about $10 \mathrm{~mm}$, but a giant tumour may protrude from the ear. Although common symptoms are ear fullness or hearing loss, asymptomatic cases are also present. 
Osteosis is an entity that is related to the ossification of connective tissue. The etiology is not clear. The tumor has a single, unilateral and smooth surface. The evolution of the disease is progressive, accompanied by symptoms such as ear fullness and hearing loss. Unlike exostosis, these tumors are rarely bilateral or multiple. Indeed, in our case, exostosis interested both ears (3).

Less than $1 / 3$ of the disease is severe. Treatment of severe forms is surgery. Surgery is recommended in patients with nerve compression and useful in jobs with high contact with cold water (7).

\section{CONCLUSION}

Surfer ear must be evoked in the presence of exostosis, especially bilaterally and even in the absence of long contact with water, since many cases of SE have been reported in coastal areas. Our case suggests that the pathophysiology of this disease is not still understood very well and that other factors can be involved in the constitution of this benign tumour.

\section{ETHICAL DECLARATIONS}

Informed Consent: Written informed consent was obtained from all participants who participated in this study (Date: 20.02.2019).

Referee Evaluation Process: Externally peer-reviewed.

Conflict of Interest Statement: The authors have no conflicts of interest to declare.

Financial Disclosure: The authors declared that this study has received no financial support.

Author Contributions: All of the authors declare that they have all participated in the design, execution, and analysis of the paper, and that they have approved the final version.

\section{REFERENCES}

1. Turetsky DB, Vines FS, Clayman DA. Surfer's ear: exostoses of the external auditory canal. AJNR Am J Neuroradiol 1990; 11: 1217-8.

2. DiBartolomeo JR. Exostoses of the external auditory canal. Ann Otol Rhinol Laryngol Suppl 1979; 88: 2-20.

3. Hirose Y, Shikino K, Ikusaka M. Surfer's ear and external auditory canal exostoses. QJM: An Int J Med 2016; 109: 759.

4. Sheehy J. Osteoma of the external auditory canal. Laryngoscope 1958; 68: 1667-73.

5. Aich Litu M, Al mamun A, Alam Z, Haque R, Hanif A, Hossain A. Exostoses of the external auditory canal. Bangladesh I Otorhinolaryngol 2012; 18: 91-5.

6. Kutz JW Jr, Fayad JN. Exostosis of the external auditory canal. Ear Nose Throat J 2006; 85: 142.

7. Alexander V, Lau A, Beaumont E, Hope A. The effects of surfing behaviour on the development of external auditory canal exostosis. Eur Arch Otorhinolaryngol 2015; 272: 1643-9. 